\title{
Tree growth is more limited by drought in rear-edge forests most of the times
}

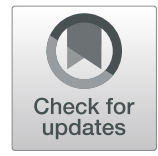

J. Julio Camarero ${ }^{1 *}$ D, Antonio Gazol ${ }^{1}$, Gabriel Sangüesa-Barreda², Marta Vergarechea ${ }^{3}$, Raquel Alfaro-Sánchez ${ }^{4}$, Nicolás Cattaneo ${ }^{3}$ and Sergio M. Vicente-Serrano ${ }^{1}$

\begin{abstract}
Background: Equatorward, rear-edge tree populations are natural monitors to estimate species vulnerability to climate change. According to biogeographical theory, exposition to drought events increases with increasing aridity towards the equator and the growth of southern tree populations will be more vulnerable to drought than in central populations. However, the ecological and biogeographical margins can mismatch due to the impact of ecological factors (topography, soils) or tree-species acclimation that can blur large-scale geographical imprints in trees responses to drought making northern populations more drought limited.

Methods: We tested these ideas in six tree species, three angiosperms (Fagus sylvatica, Quercus robur, Quercus petraea) and three gymnosperms (Abies alba, Pinus sylvestris and Pinus uncinata) by comparing rear-edge tree populations subjected to different degrees of aridity. We used dendrochronology to compare the radial-growth patterns of these species in northern, intermediate, and southern tree populations at the continental rear edge.

Results and conclusions: We found marked variations in growth variability between species with coherent patterns of stronger drought signals in the tree-ring series of the southern populations of $F$. sylvatica, $P$. sylvestris, and A. alba. This was also observed in species from cool-wet sites (P. uncinata and Q. robur), despite their limited responsiveness to drought. However, in the case of $Q$. petraea the intermediate population showed the strongest relationship to drought. For drought-sensitive species as F. sylvatica and $P$. sylvestris, southern populations presented more variable growth which was enhanced by cool-wet conditions from late spring to summer. We found a trend of enhanced vulnerability to drought in these two species. The response of tree growth to drought has a marked biogeographical component characterized by increased drought sensitivity in southern populations even within the species distribution rear edge. Nevertheless, the relationship between tree growth and drought varied between species suggesting that biogeographical and ecological limits do not always overlap as in the case of Q. petraea. In widespread species showing enhanced vulnerability to drought, as F. sylvatica and P. sylvestris, increased vulnerability to climate warming in their rear edges is forecasted. Therefore, we encourage the monitoring and conservation of such marginal tree populations.
\end{abstract}

Keywords: Climate change, Dendroecology, Latitudinal gradient, Mediterranean forests, Standardized evapotranspiration precipitation index (SPEI)

\footnotetext{
* Correspondence: jjcamarero@ipe.csic.es

${ }^{1}$ Instituto Pirenaico de Ecología (IPE-CSIC), Avda. Montañana 1005, E-50192

Zaragoza, Spain

Full list of author information is available at the end of the article
}

\section{Springer Open}

(c) The Author(s). 2021 Open Access This article is licensed under a Creative Commons Attribution 4.0 International License, which permits use, sharing, adaptation, distribution and reproduction in any medium or format, as long as you give appropriate credit to the original author(s) and the source, provide a link to the Creative Commons licence, and indicate if changes were made. The images or other third party material in this article are included in the article's Creative Commons licence, unless indicated otherwise in a credit line to the material. If material is not included in the article's Creative Commons licence and your intended use is not permitted by statutory regulation or exceeds the permitted use, you will need to obtain permission directly from the copyright holder. To view a copy of this licence, visit http://creativecommons.org/licenses/by/4.0/. 


\section{Background}

Climate warming impacts the productivity and functioning of forest ecosystems worldwide with consequences on the services they provide for human wellbeing (Anderegg et al. 2013; Hartmann et al. 2018). Recent warming trends have accelerated tree growth in temperature-limited forests (Serreze and Barry 2011), while they have caused widespread drought-related mortality in most biomes (Allen et al. 2010; Choat et al. 2018). Drought is becoming a major driver of tree growth globally (Babst et al. 2019) revealing a temporal instability in its impacts on forests over the last decades (Peltier and Ogle 2020; Wilmking et al. 2020). Along with this, the role of drought in determining tree growth is also spatially variable (Anderegg et al. 2015), with tree populations located near the equatorward distribution limit being more vulnerable to drought (e.g., SánchezSalguero et al. 2017; but see Cavin and Jump 2017). Therefore, when trees are not adapted to harshening environmental conditions, widespread dieback and mortality occur leading to the range contraction of the species distribution limit (Anderegg and HilleRisLambers 2016; Anderegg et al. 2019). However, recent studies have demonstrated that populations on the equatorward limit display adaptations to drought (Dorado-Liñán et al. 2019; Muffler et al. 2020) and that ecological factors can blur or override geographical patterns of greater vulnerability to drought as latitude decreases (Vilà-Cabrera and Jump 2019). In other words, marginality has different components (i.e., geographical, ecological, and genetic) and geographical range margins do not always dictate population performance (Vilà-Cabrera et al. 2019).

According to biogeographical expectations, as climate becomes warmer and drier, rear-edge tree populations of temperate or mountain species may become vulnerable to drought and show productivity and growth reductions preceding dieback events (Camarero et al. 2017). Several Eurasian tree species reach their southern distribution limit in Spain (de Vries et al. 2015), where droughtlimitations on species performance and vitality have been already reported and are expected to increase (Lindner et al. 2010; Camarero et al. 2015). Even within Spain, southern or low altitudinal forests of some species such as Scots pine can be more vulnerable to drought than forests located at higher elevations or latitudes in the rear edge (Marqués et al. 2016; Serra-Maluquer et al. 2019). These reasons make some Spanish forests a valuable proxy of drought impacts on European rear-edge tree populations.

Tree populations of species such as silver fir (Abies alba Mill.) present lower growth rates in some Pre-Pyrenean sites of northern Spain than in other wetter regions of Central Europe (Gazol et al. 2015). Similarly, Scots Pine (Pinus sylvestris L.) and European beech (Fagus sylvatica
L.) populations show greater sensitivity to drought in dry regions of Spain than in northern or wetter areas (SerraMaluquer et al. 2019; Bose et al. 2020). However, local ecological conditions can affect the growth responsiveness of these species and populations to climate making rearedge populations less vulnerable to drought than their northern counterparts (Dorado-Liñán et al. 2019). This contingency on site conditions has been shown in silver fir forests in the Spanish Pyrenees (Camarero et al. 2011), Scots pine in southern Spain (Herrero et al. 2013), or European beech forests in north eastern Spain (VilàCabrera and Jump 2019). Thus, the growth response to drought of rear-edge tree populations can deviate from biogeographical predictions due to the influence of local ecological factors or genetic adaptations to drought (Vilà-Cabrera et al. 2019).

Several factors can contribute to the strong variability in tree growth response to drought between populations decoupling biogeographical and ecological margins (Vilà-Cabrera et al. 2019). Thus, population performance may depend on the interaction between different ecological factors, climate-competition trade-offs (e.g., Jump et al. 2017; Anderegg and HilleRisLambers 2019), or phenotypic plasticity and genetic variability (Hampe 2004; Valladares et al. 2015). For example, Herrero et al. (2013) and Marqués et al. (2016) found that Scots pine rear-edge populations were vulnerable to drought at low elevations, where the evapotranspiration demand increases, while at high elevations growth was less constrained by water shortage. Altitudinal variations can decouple local microclimate conditions from regional macroclimatic patterns affecting tree growth response to climate but also competitive interactions (Anderegg and HilleRisLambers 2019). That is, within the rear edge those populations at lower elevations were more vulnerable to drought. Muffler et al. (2020) found that European beech rear-edge populations did not respond to drought as compared to central populations and attributed this effect to the cooling effects of local fog events or high elevation mitigating drought impacts (see also Rozas et al. 2015; Barbeta et al. 2019). In such situations, plant-soil interactions, and the capacity of trees to compete within their neighbourhood may play an important role in enhancing or limiting drought impacts (Leuschner 2020). Marqués et al. (2018) found that the response of growth of Scots pine to drought in rear-edge populations was modulated by stand density, pointing to the impact of past forest management on recent growth vulnerability, as has been found for other species (Camarero et al. 2011; Pérez-Luque et al. 2020). RubioCuadrado et al. (2020) found competition due to the cessation of traditional management as the main driver of growth in a rear edge, mixed broadleaved forest. These variations between populations can be even more apparent 
when different species are considered given the contrasted sensitivity to drought between drought-sensitive species such as European beech and Scots pine or tolerant species such as pedunculate oak (Quercus robur L.) (Vitasse et al. 2019). These results question the universal validity of the hypothesis of a greater vulnerability of tree growth to drought near their rear edge (Vilà-Cabrera et al. 2019; Muffler et al. 2020). Further, they indicate that regional studies over geographically and climatically contrasting tree populations are required to decipher if rear-edge populations are the most vulnerable to drought across a species distribution range. In this sense, it is expected that if tree populations are climatically different or geographically distant, rear-edge populations will be consistently more constrained by drought events as they face harsher environmental conditions (Anderegg and HilleRisLambers 2019). However, genetic adaptations can make rear-edge populations less vulnerable to drought (Vilà-Cabrera et al. 2019).
Here we tested the hypothesis that even within the rear edge those tree populations located in southern sites are subjected to drier conditions and thus display greater growth vulnerability to drought than populations located in intermediate or northern sites. Alternatively, tree populations of a species in intermediate and northern sites have not experienced an equally strong selection for drought resistance because they are less adapted to experience severe drought than those towards the species' moisture-limited range margin. Therefore, one would expect southern, equatorward populations would be less impacted by drought of a given severity than would be poleward populations. To test these ideas, we selected six species widely distributed in Europe that found their rear-edge distribution limit in Spain. The species were three gymnosperms (Pinus sylvestris, Abies alba and Pinus uncinata Ram.) and three angiosperms (Fagus sylvatica, Quercus robur and Quercus petraea (Mattuschka) Liebl.) forming rear-edge populations in north-eastern Spain (Fig. 1). For each species in each site,
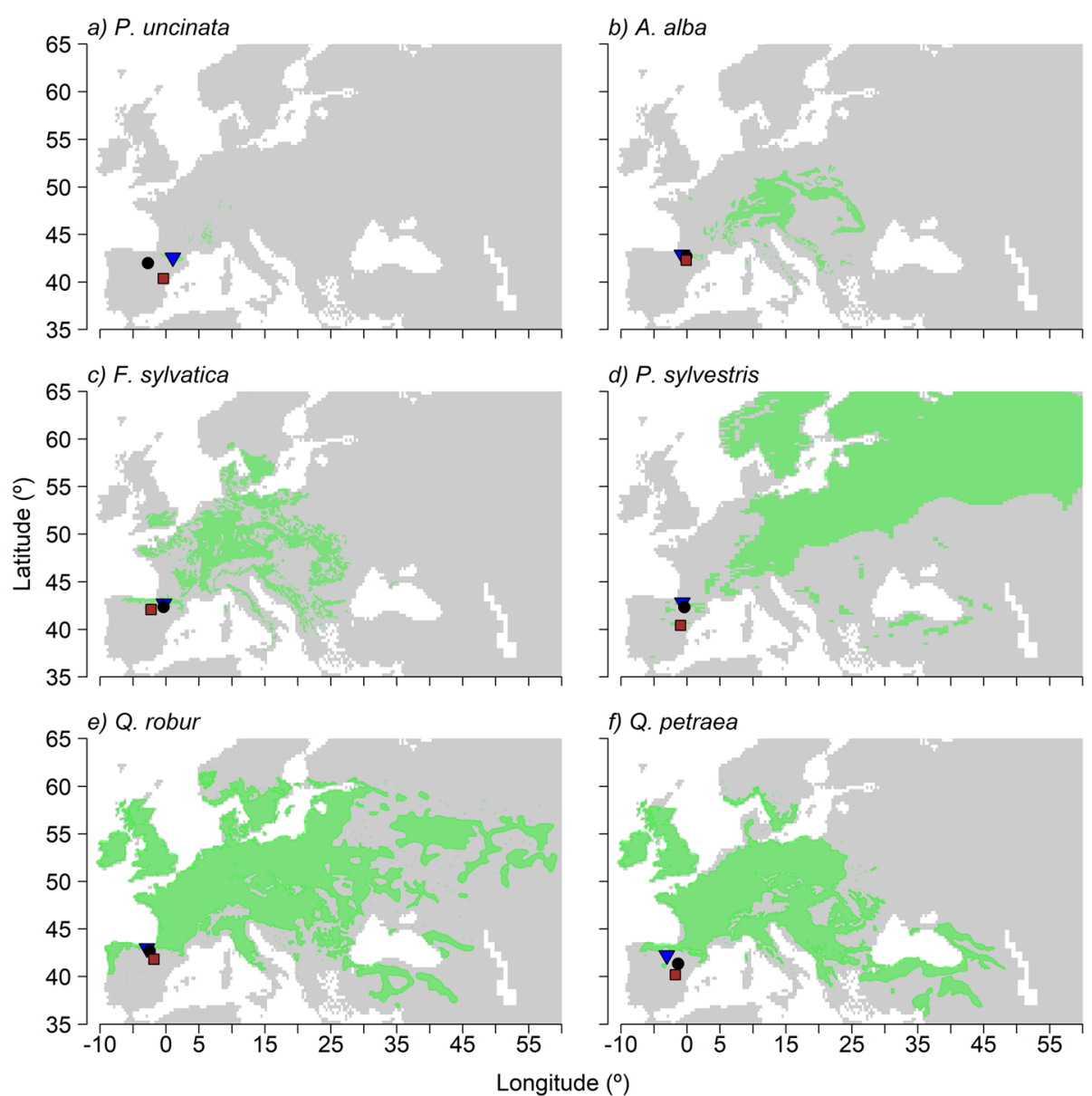

Fig. 1 Distribution maps of the studied species across Europe. For each species (a, Pinus uncinata; b, Abies alba; $\mathbf{c}$, Fagus sylvatica; d, Pinus sylvestris; e, Quercus robur; $\mathbf{f}$, Quercus petraea) the green area represents the distribution of the species in Europe. The dots in the graph indicate the location of the northern (blue triangle), intermediate (black circle) and southern or rear-edge (red squares) 
we used dendrochronology to reconstruct past radialgrowth patterns by accurately dating tree-ring width records. We expected: (i) higher growth variability, and lower mean growth, in southern as compared to intermediate and northern populations; (ii) stronger coupling between growth variability and drought stress in southern populations; and (iii) an increasing growth sensitivity to drought in southern populations during the last decades.

\section{Methods}

\section{Studied sites and tree species}

We studied six common European tree species (three Pinaceae and three Fagaceae) widely distributed in Europe (Figs. 1 and S1) namely: P. uncinata, A. alba, P. sylvestris, $F$. sylvatica, $Q$. robur and $Q$. petraea. Mountain pine $(P$. uncinata) is a species distributed in central and southwestern European mountains finding its southern distribution limit in the Iberian System, eastern Spain (Camarero et al. 1998). Silver fir (A. alba) is an economically profitable species widely distributed in central and southwestern Europe with rear-edge populations in north-eastern Spain mountains as the PrePyrenees (Gazol et al. 2015). Scots pine (P. sylvestris) and European beech (F. sylvatica) also find their southwestern distribution limits in Spain where droughtinduced dieback has been reported for both species (Camarero et al. 2015, 2017). Pedunculate (Q. robur) and sessile (Q. petraea) oaks are widely distributed from northern to southern Europe and they form pure or mixed stands, where they can hybridize, in wet sites (e.g. valley bottoms) or mountain sites of north-eastern Spain (Caudullo et al. 2017).

\section{Field sampling and laboratory work}

Three sites with contrasting climatic conditions, and always including a drier rear-edge site, were selected for each species (Table 1; Figs. 1 and 2). In each species, the driest, rear-edge site presented lower precipitation than the other two sites (Figs. 2 and S2). We quantified radial growth because this is a reliable proxy of tree vigour changes in response to drought (Dobbertin 2005). We sampled at least 15 dominant trees for each species and site. All sites form mixed stands excepting the pure Betato and Poyales F. sylvatica sites, and the Tessó del Son $P$. uncinata site situated near the alpine treeline. The diameter at breast height of each tree (Dbh) was measured at $1.3 \mathrm{~m}$ using a metric tape. Two cores (see Table 1) were extracted per tree at $1.3 \mathrm{~m}$ using $5-\mathrm{mm}$ increment borers, and perpendicular to the main stem and the slope. Then, cores were air-dried, glued, and polished using a series of sand-paper grits until tree-ring boundaries were clearly visible. These samples were visually cross-dated and measured to the nearest $0.01 \mathrm{~mm}$ using a LINTAB measuring device (Rinntech, Heidelberg,
Germany). Cross-dating accuracy was checked by using the software COFECHA (Holmes 1983).

Mean growth series or chronologies were created for each site and species by detrending tree-ring width measures (Fritts 1976). Individual tree-ring width series were detrended using a cubic smoothing spline with a 50\% frequency response cut-off at 30 years (Cook and Peters 1981). The ring width index (RWI) for each series was obtained by dividing the observed and fitted tree-ring width values. Pre-whitened RWI series were calculated by removing temporal autocorrelation using autoregressive models. The resulting standardized, pre-whitened individuals RWI series were averaged into mean site chronologies for each species using bi-weight robust means.

To characterize the species' chronologies of each site for the common period 1950-2000 we calculated the following tree-ring statistics: mean, standard deviation and coefficient of variation (CV) of tree-ring width; mean correlation between indexed, individual series (rbar); and the Expressed Population Signal (EPS), a measure of replication and internal coherence of each chronology (Fritts 1976). The Dunnett's modified Tukey-Kramer pairwise multiple comparison test (Dunnett 1980) was used to compare tree-ring width of individuals between southern, intermediate and northern populations for each species.

\section{Climatic and distribution data}

For each species, distribution maps were downloaded from the EUFORGEN website (http://www.euforgen.org/ species/; de Vries et al. 2015) and they were completed using recent distribution data across Europe (Caudullo et al. 2017). The European distribution maps of each species were compared with climate data to describe the climatic niche of each species. To this end, maps of mean annual temperature (MAT) and mean annual precipitation (MAP) were downloaded from the WorldClim database (https://www.worldclim.org/; Fick and Hijmans 2017). These maps represent averages over the period 1970-2000 and show global patterns in climate. Then, we plotted each site in a MAT vs. MAP graph considering the European distribution area of the study species, i.e. between $12^{\circ} \mathrm{W}-60^{\circ} \mathrm{E}$, and $32^{\circ}-72^{\circ} \mathrm{N}$ (Fig. 2).

To quantify climate-growth relationships, monthly mean temperature and precipitation data from the EOBS database v. 20.0e (Haylock et al. 2008) were downloaded at $2.5^{\circ}$ resolution for the period 1950-2018 using the Climate Explorer webpage (https://climexp.knmi.nl/ start.cgi). To quantify drought impact, we used the Standardized Evapotranspiration Precipitation Index (SPEI; Vicente-Serrano et al. 2010). The SPEI is a multi-scalar index that quantifies drought intensity based on the difference between precipitation and the atmospheric evaporative demand for different periods, with negative 


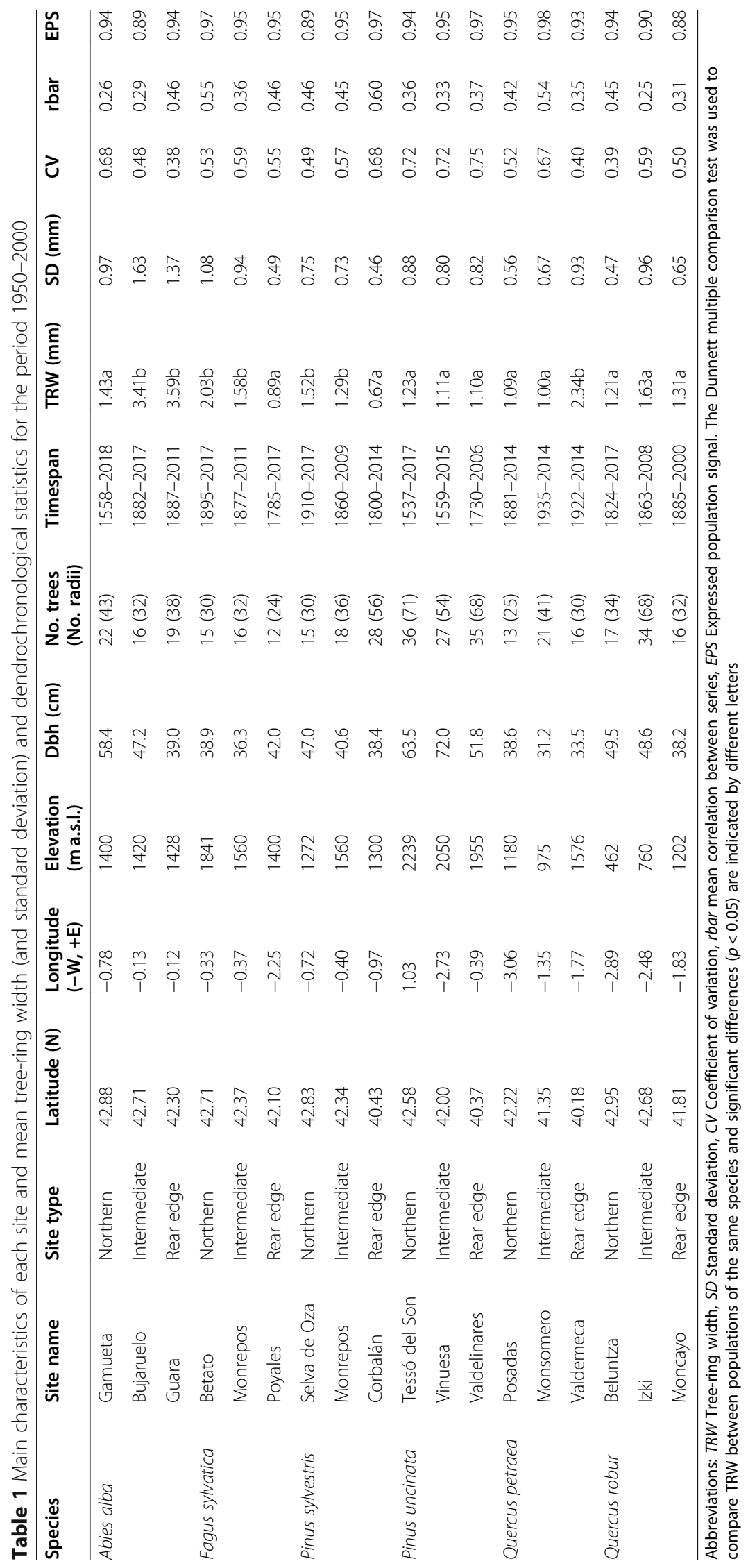


a) P. uncinata
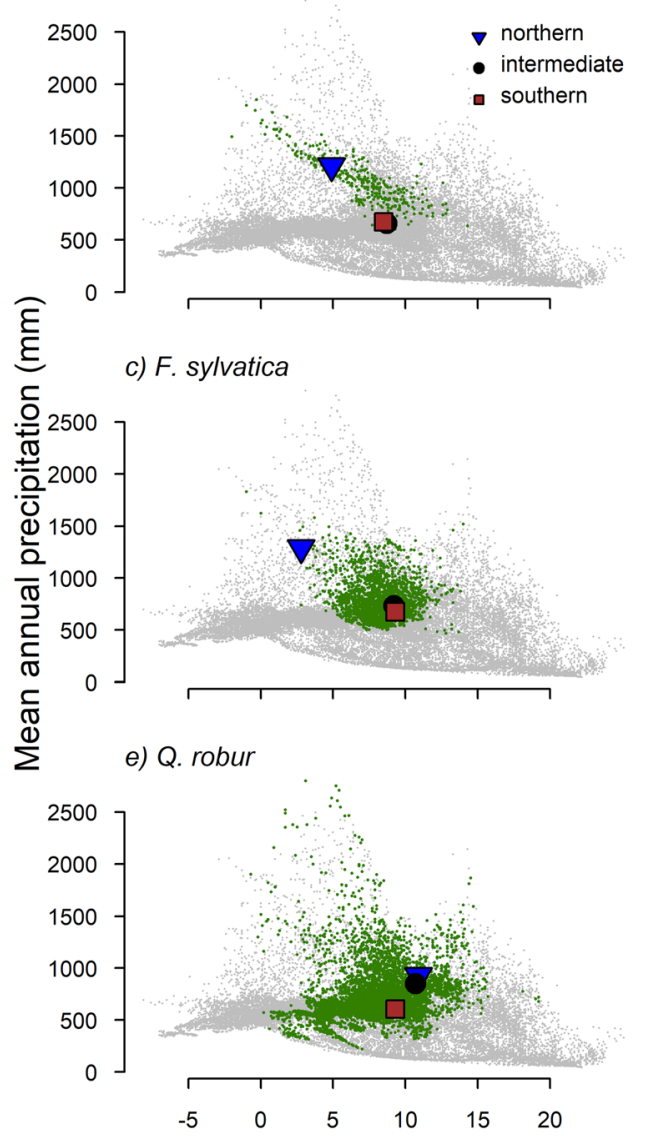

b) A. alba

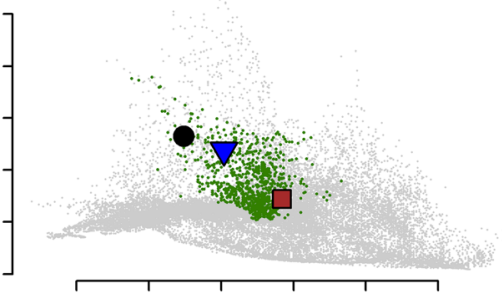

d) P. sylvestris

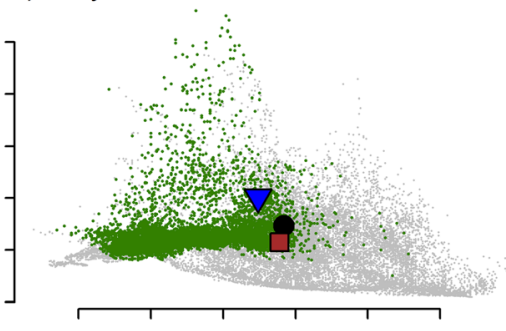

f) Q. petraea

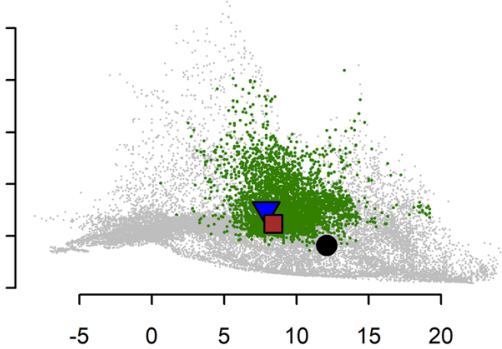

Mean annual temperature $\left({ }^{\circ} \mathrm{C}\right)$

Fig. 2 Representation of each studied species in the climatic space (Worldclim data; Fick and Hijmans 2017) The green dots represent values of mean annual temperature and total precipitation where the species are present in Europe (a, Pinus uncinata; $\mathbf{b}$, Abies alba; $\mathbf{c}$, Fagus sylvatica; $\mathbf{d}$, Pinus sylvestris; e, Quercus robur; $\mathbf{f}$, Quercus petraea). Climate data was downloaded for the distribution of the species in Europe (http://www. euforgen.org/species/). Grey dots represent values of temperature and precipitation where the species are not found in Europe. The dots in the graph indicate the location of the tree populations of each species

values indicating water scarcity. We used 1-48 month SPEI timescales for the period 1962-2016 for the sampled forest sites from a high spatial resolution gridded dataset for Spain based on quality controlled and homogenised meteorological series (Vicente-Serrano et al. 2017).

\section{Statistical analyses}

The relationships between tree growth (RWI) and monthly mean temperature and precipitation (deviations with respect to the mean temperature and precipitation values at a site) were quantified for the best-replicated period 1950-2006 using bootstrapped Pearson correlations (Meko et al. 2011). These analyses were performed from September in the year before the tree-ring was formed to September of the year of tree-ring formation (hydrological year). Moving correlation functions were applied to assess the dynamic nature of the relationships between RWI and relevant climate variables (precipitation, temperature and July SPEI) and considering 30year moving windows. We used July SPEI as tree growth for many tree species in north-eastern Spain, where most of our studied populations are located, have been found to respond to drought from June up to August (Pasho et al. 2011). Analyses were performed using the "dplR" (Bunn 2008), the "treeclim" (Zang and Biondi 2015), and the "visreg" libraries (Breheny and Burchett 2017) of the R statistical software ( $R$ Core Team 2020).

\section{Results}

The "climatic space" plot allowed to characterize the climate conditions of geographically southern populations from the other species sites (Fig. 2). This differentiation was clear in the case of $A$. alba, and less evident in $P$. sylvestris, and Q. robur. In P. uncinata and F. sylvatica intermediate and southern sites shared similar annual 
climatic conditions (Fig. S2). Lastly, in Q. petraea the warmest and driest conditions (highest MAT and lowest MAP) were observed in the intermediate site, and not in the southern site.

We found marked growth differences across populations for some species (Table 1). Lower growth rates in the southern sites were more evident for drought-sensitive species such as F. sylvatica and P. sylvestris (Table 1; Fig. S3). Growth rates of $A$. alba individuals were higher in the intermediate and southern sites than in the northern site, and the largest growth rates in the case of Q. petraea were found in the southern site (Table 1; Fig. S3). Growth variability varied considerably between species. Tree species inhabiting cold and wet sites (A. alba, Q. robur), but not $P$. uncinata, displayed lower growth variability (Fig. 3 and Table 1) than P. sylvestris and F. sylvatica. Q. petraea was the only exception in which growth variability was stronger in the central than in the rear-edge site (Fig. 3). In this respect, the average correlation between series (rbar) and the coefficient of variation in TRW were higher in its intermediate site than in the other two populations
(Table 1). This result contrasts with species such as $P$. sylvestris and $A$. alba that showed the highest rbar values but either higher or lower growth variability in their respective southern sites.

The relationship between growth and climate displayed different patterns between species and sites (Fig. 4). In the case of A. alba and Q. robur we found a greater dependency of growth on summer precipitation in southern sites than in the other two populations. In A. alba and P. sylvestris warmer summer temperatures negatively impacted tree growth in southern sites (Fig. 4). This negative correlation was also observed in the northern $P$. sylvestris site, and particularly in the intermediate $Q$. petraea site which depended on prior-winter and spring precipitation. This dependency on the amount of rainfall received before or early in the growing season was also observed in southern F. sylvatica and $P$. sylvestris sites. The growth of $P$. uncinata and A. alba in southern populations, and P. uncinata and $P$. sylvestris in intermediate populations, was negatively related to temperature of September in the year prior to tree-ring formation. In the $A$. alba and F. sylvatica a) P. uncinata

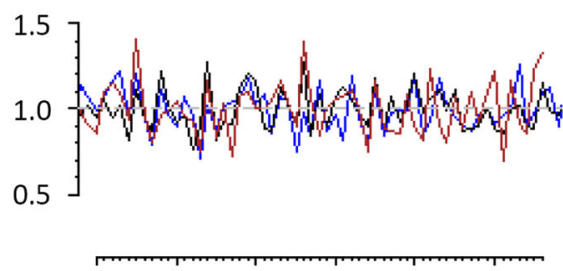

c) F. sylvatica

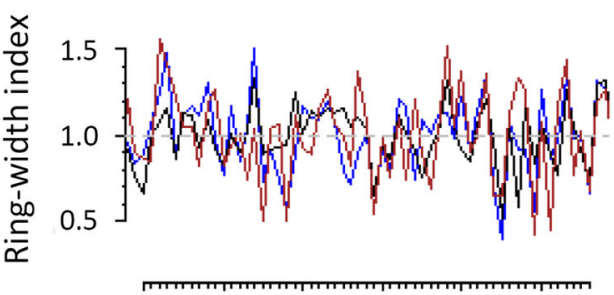

e) Q. robur b) A. alba

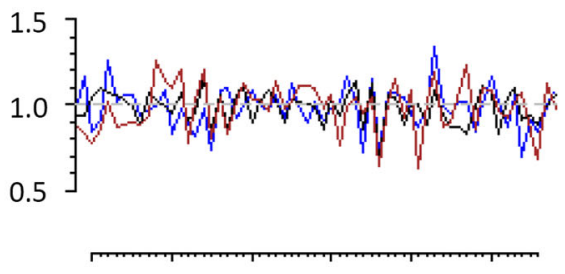

d) P. sylvestris

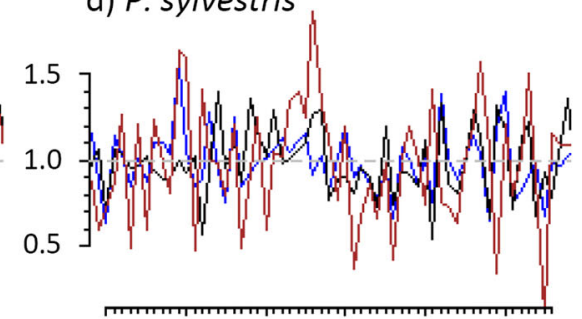

f) Q. petraea

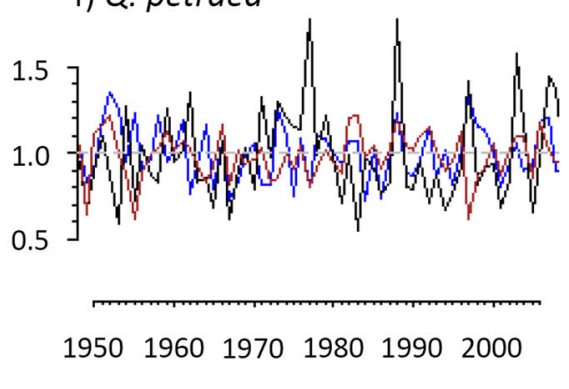

Year

Fig. 3 Mean series of ring-width indices (RWI) of the six species (a, Pinus uncinata; $\mathbf{b}$, Abies alba; c, Fagus sylvatica; d, Pinus sylvestris; e, Quercus robur; f, Quercus petraea) studied in the northern (blue), intermediate (black) and southern (brown) tree populations for the period 1950-2006 


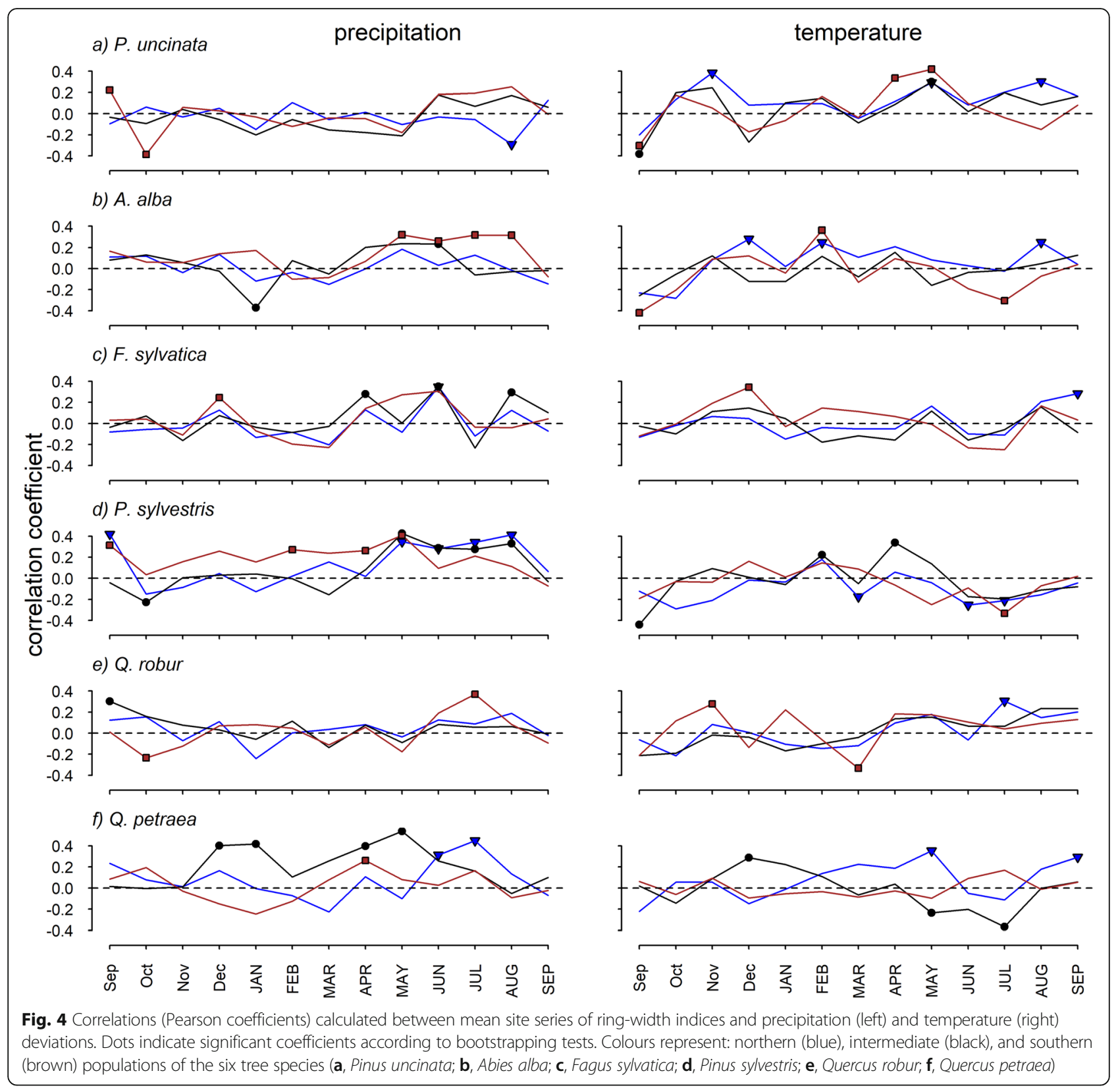

southern populations, prior-winter temperatures were positively correlated with growth.

For all species except $Q$. robur, the negative impact of summer temperatures on growth has increased over the last decades (Figs. 5 and S4). This was evident at the southern sites of some species (P. uncinata, A. alba, $F$. sylvatica), whereas in others it was observed in all sites ( $P$. sylvestris). In Q. petraea, growth decreased in response to increasingly warmer summer conditions in the intermediate site. The temporal evolution of the correlation between growth and precipitation was less clear, but spring precipitation gained importance in the intermediate sites of F. sylvatica, P. sylvestris and Q. petraea (Figs. 5 and S5).
Unexpectedly, the strongest correlation between the SPEI and growth was found for Q. petraea in the intermediate population (Fig. 6). According to our expectations, we found a stronger correlation between SPEI and growth in the southern than in the other two sites for three out of the six species studied. This was the case of the drought-sensitive species F. sylvatica and P. sylvestris, and A. alba. Differences between populations were less evident in Q. robur and P. uncinata. The temporal evolution of the correlation between growth and SPEI showed that in the southern $P$. sylvestris population there was a marked increase in the vulnerability of growth to long droughts (12- to 18-month SPEI values; 


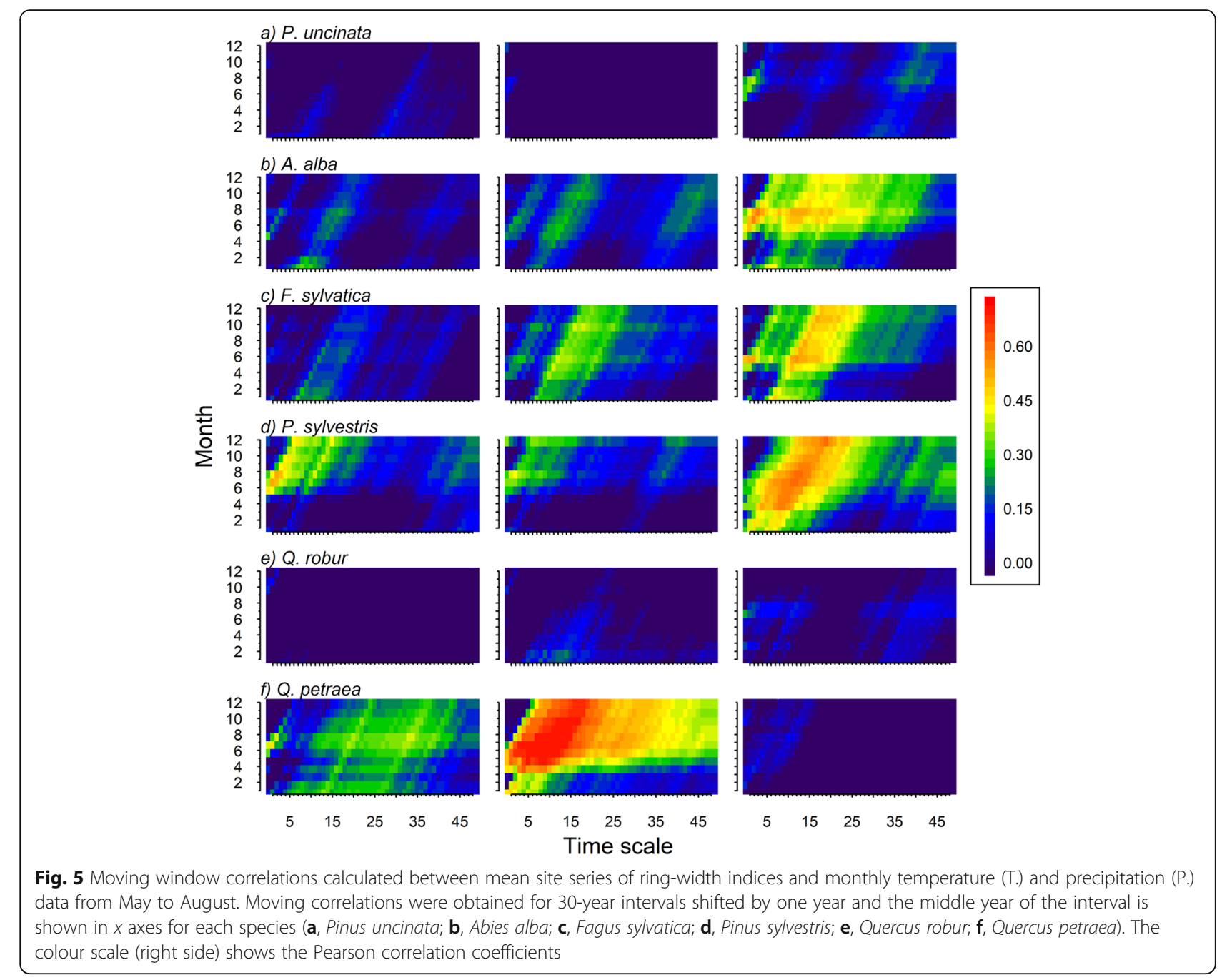

Figs. 7 and S6). In the rear-edge $A$. alba site, there was a persistence influence of short- and mid-term droughts on growth, and, again, this influence was more evident in the intermediate $Q$. petraea site.

\section{Discussion}

We found that drought is a major factor limiting tree growth for most of the studied species and sites near the rear edge of their distribution range. According to our expectations, drought-sensitivity increased towards the equatorial border of the species distribution range for most of the species studied. That is, populations located in southern sites were in general more vulnerable to drought than populations located in intermediate or northern sites. In accordance, growth sensitivity to drought varied markedly among tree populations within each species (Fig. 6). For drought-sensitive species as Scots pine, the results showed that tree growth is more limited by drought in the southern site (Figs. 6 and 7). This negative impact has been exacerbated due to the increase in growing-season temperatures, and probably evapotranspiration rates, over the past decades (VicenteSerrano et al. 2015). Our findings evidence the drought vulnerability of tree species such as silver fir, European beech and Scots pine (see also Vitasse et al. 2019; Bose et al. 2020). There is a notable exception in the case of sessile oak, a drought-sensitive species (Aranda et al. 2000), whose growth is more impacted by drought in intermediate than in southern populations, pointing to the importance of other ecological or local factors modulating tree growth sensitivity to drought (Cavin and Jump 2017). The intermediate and southern sites are separated by $120 \mathrm{~km}$ (Fig. S1) and the highest responsiveness to drought was observed in the climatic limit or most xeric site (Monsomero). This site was also formerly exploited as a coppice forest about 60 years ago (JJ Camarero, pers. observ.), which could have exacerbated its current sensitivity to drought due to competition among stems of the same individual (Corcuera et al. 2006; Pérez-Luque et al. 2020). The case of Q. petraea shows 


\section{a) P. uncinata}

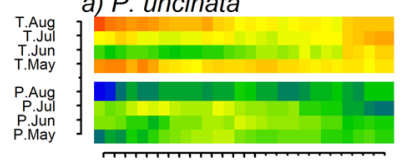

b) A. alba

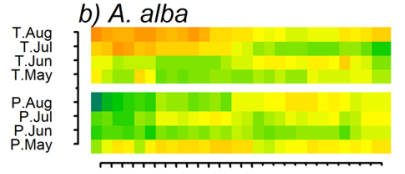

c) F. sylvatica
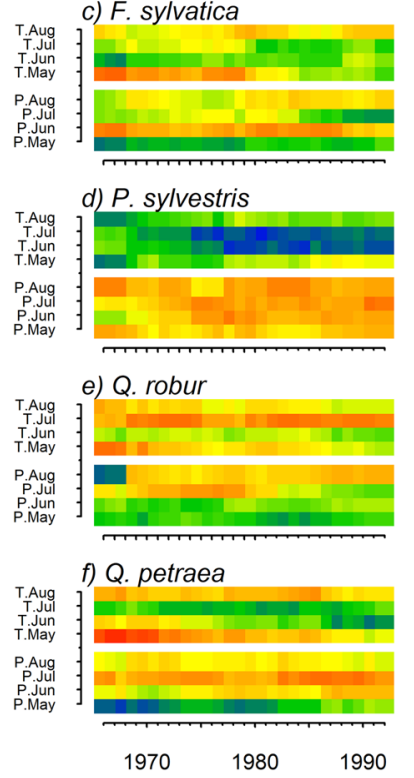

f) Q. petraea
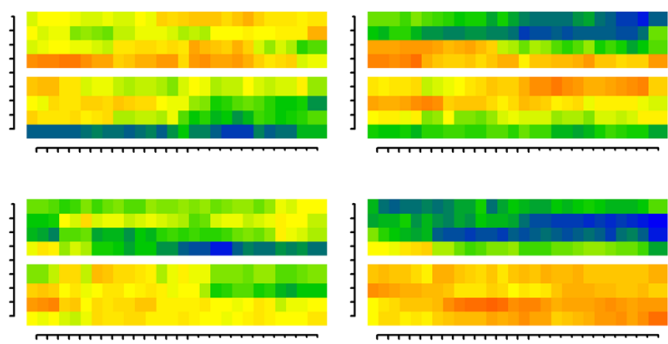

\section{;}
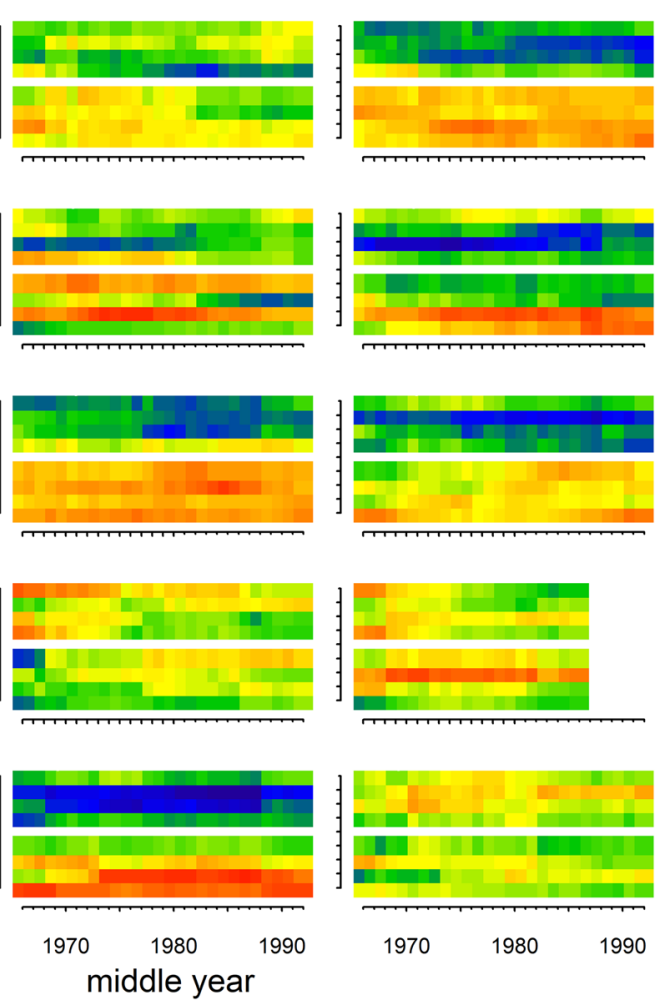

Fig. 6 Correlations between mean site series of ring-width indices and the SPEI drought index calculated at 1- to 48-month temporal resolution ( $x$ axes) and from January to December ( $y$ axes). Northern, intermediate and southern populations are represented for the six species (a, Pinus uncinata; b, Abies alba; c, Fagus sylvatica; $\mathbf{d}$, Pinus sylvestris; e, Quercus robur; $\mathbf{f}$, Quercus petraea). The colour scale shows the Pearson correlations

that other ecological factors besides climate can constrain the growth responsiveness to drought and can modify latitudinal patterns of drought sensitivity. Recent studies have pointed out that discrepancies between micro and macroclimate conditions, interactions between ecological factors, species interactions and genetic adaptations can play an important role in driving growth response to drought, despite biogeographical differences being important (Vilà-Cabrera et al. 2019). The lack of reliable information on local conditions only allows us to speculate on the factors that make intermediate and northern populations less vulnerable to drought than southern populations in some cases. Solving this question will require a more holistic approach to understand the interactions between geographical, ecological and historical factors. Overall, the presented results enlighten that rear-edge populations are, most of the times, reliable monitors of the long-term response of drought-sensitive tree species to climate change and show that most tree populations are more vulnerable to drought southwards.
The six studied species are widely distributed in Europe, excepting the mountain pine ( $P$. uncinata), and find their southwestern distribution limit in Spain. However, as occurs with the geographical and climatic extents of their distribution ranges (Figs. 1 and 2), the drought sensitivity of each species varies notably (Fig. 6). In the mountain pine we found that its growth in the region is controlled by late-spring and early-summer temperatures (Fig. 4a), in line with previous studies (e.g., Camarero et al. 1998; Tardif et al. 2003), but we also found a low drought susceptibility in the rear edge which could be explained by ontogenic or genetic differences (Galván et al. 2014; González-Díaz et al. 2020). This contrast with what was found for Scots pine, a widely distributed drought-sensitive species (DoradoLiñán et al. 2019; Bose et al. 2020). Despite growth positively responded to summer precipitation and negatively to summer temperature in all studied Scots pine sites, the response occurred earlier (in the case of temperature) and was more intense in the southern site. In this site, an 

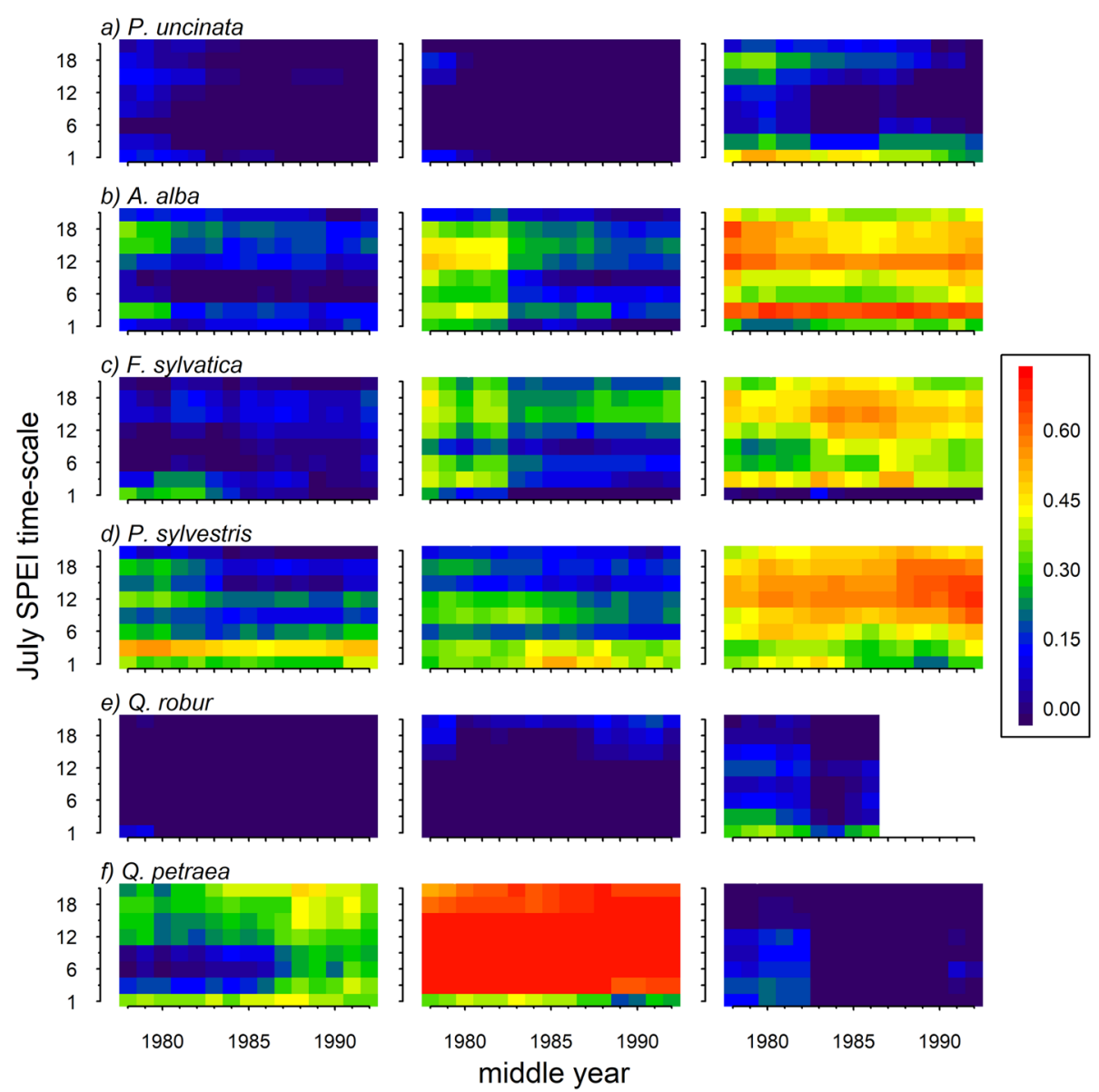

Fig. 7 Moving window correlations calculated by relating mean site series of ring-width indices and the July SPEl drought index at 1-, 3-, 6-, 9-, 12-, 15-, 18-, and 21-month temporal resolutions (y axes). Moving correlations were obtained for 30-year intervals shifted by 1 year and the middle year of the interval is shown in $x$ axes for each species (a, Pinus uncinata; $\mathbf{b}$, Abies alba; $\mathbf{c}$, Fagus sylvatica; $\mathbf{d}$, Pinus sylvestris; e, Quercus robur; f, Quercus petraea). The colour scale shows the Pearson correlation coefficients

acute dieback episode started after the severe 2012 drought and resulted in the death of many Scots pine trees (Camarero et al. 2015; Gazol et al. 2018). The significantly lower growth rates and the larger vulnerability of tree populations to drought and warmer conditions in this region as compared to other populations, together with the observed lack of recruitment of Scots pine, point towards major compositional changes and the replacement of that species by more drought-tolerant oak and juniper species (Gazol et al. 2018).

Our results also highlighted the drought sensitivity of European beech in line with previous research (SerraMaluquer et al. 2019; Vitasse et al. 2019; Wilmking et al. 2020). Both, Scots pine and European beech have been recognized as drought-sensitive species in terms of growth loss (Dorado-Liñán et al. 2019) despite their marked differences in functional traits including stomatal control in response to drought (Klein 2014). Scots pine is a species with a tight stomata regulation (Klein 2014), and thus very vulnerable to early summer droughts, which is corroborated in our study by the earlier sensitivity of growth to precipitation and SPEI in the southern site (Figs. 4 and 6). It has been found that the stomatal control over water loss and the leaf area / sapwood area ratio change along gradients of dryness in Scots pine (Martínez-Vilalta et al. 2009), which can also explain the lower growth rates found in the southern site. The sensitivity of European beech to drought increased also notably in the southern site, but no clear changes in temperature-growth couplings were found in this species (Fig. 4). European beech presents large geographical differences in drought-response across its distribution area since southern populations are located in mountain areas, which allow mitigating Mediterranean drought stress, and present local adaptations related to leaf phenology (Peaucelle et al. 2019; Vilà-Cabrera et al. 2019; Wilmking et al. 2020; Leuschner 2020). However, we found that the growth rates were lower and the vulnerability of European beech growth to drought was stronger in the southern as compared to the other two populations 
(Fig. 6), suggesting that the tightest responses to drought occur in the driest site (Fig. 2), and pointing to the importance of geographical differences in climate as drivers of European beech growth (Dorado-Liñán et al. 2019).

Special attention should be paid to silver fir, a species that has been found to be resistant and resilient to spring droughts (Vitasse et al. 2019), but that has showed drought-induced dieback in some Spanish Pyrenean populations over the last decades (e.g., Camarero et al. 2011; Gazol et al. 2015, 2020). The large difference in growth rates found between the northern and the other two populations can be explained by the matureness of the old-growth Gamueta site (Molina-Valero et al. 2021). Thus, site conditions modulated growth rates but not the vulnerability to drought, which increased in the southern sites. Silver fir displayed larger sensitivity of tree growth to drought in the southern site, in line with the observed vulnerability of the species to drought in the Pyrenees (Camarero et al. 2011). In central Europe, silver fir is one of the most productive tree species (Vitasse et al. 2019). However, this contrasts with the observed growth reductions and loss of vitality observed in some Pyrenean sites (Gazol et al. 2015). In this region, low-altitude forests are suffering exacerbated growth sensitivity to drought and warmer conditions in comparison with other colder sites located at higher elevations. The prevalence of the species in rear-edge sites is extremely contingent on sufficient precipitation during the summer months (Fig. 4), but also on the existence of a positive water balance in the year before tree-ring formation (Fig. 6) which depends on summer temperatures (Vicente-Serrano et al. 2015). Over the last decades, the dependency of silver fir growth on summer temperature has increased (Fig. 5) suggesting that the occurrence of hotter summers as a consequence of climate change may negatively impact the species rear-edge (Sánchez-Salguero et al. 2017). We cannot obviate the fact that Iberian populations of silver fir are genetically differentiated from core populations situated in Central Europe (Gazol et al. 2015).

Pedunculate oak (Q. robur) showed no clear responses to drought at the rear edge as it can be expected for this drought-tolerant species (Vitasse et al. 2019). Climate-growth correlations showed that growth depended on wet conditions during the growing season, with a negative signal of March temperatures in the southern site. This signal can be due to a shift in the use of stored carbohydrates allowing an earlier expenditure and reducing its availability to produce new leaves and earlywood vessels, thus decreasing hydraulic conductivity (Alla and Camarero 2012). The response of pedunculate oak growth to precipitation during summer (Fig. 4) is in line with the response of the species to drought in nearby sites (Rozas 2001; Granda et al. 2017).
The response of pedunculate oak to drought contrasts with the response of sessile oak (Q. petraea) that showed a marked reaction of growth to temperature, precipitation, and drought (Figs. 4, 5 and 6), particularly in the intermediate site. Wet-warm prior winter and cool-wet spring-summer conditions improved its growth in the drought-sensitive, intermediate site. This represents the only example in which we found a greater vulnerability of tree growth to drought in a site different from the geographical rear edge (i.e., southernmost site). Previous studies have found that site-specific conditions can alter broad biogeographical patterns resulting in mismatches between the geographical and the ecological rear edges for oak forests (Pérez-Luque et al. 2020). In this respect, the rear-edge population (Valdemeca) is located at a relatively high elevation (Table 1 ) which can milder climate conditions thus reducing negative drought impacts (Herrero et al. 2013). Further, it is a mixed forest, composed of scattered stands with Scots pine, which could reduce the evaporative demand of oak canopies thus modulating the sensitivity of trees to drought (RubioCuadrado et al. 2020). In other words, altitudinal changes decouple micro- from the macroclimate conditions thus modulating the vulnerability of tree growth to drought.

Finally, the distributions of many tree species are out of equilibrium with climate at their range margins (Talluto et al. 2007). The high longevity and limited dispersal ability of trees explain their extinction debts near the warmer, equatorward margins of their distribution ranges. Thus, rear-edge tree populations could persist under unsuitable climate conditions despite of increasing climate-distribution disequilibrium (Svenning and Sandel 2013). We show that tree-ring data are suitable monitors of rapid forest responses to climate and drought and could complement other variables (e.g., recruitment and mortality rates). Since tree species rear edges are predicted to experience contraction in response to climate warming (Talluto et al. 2007), conservation and management strategies could use retrospective growth assessments to quantify how trees respond to climate warming and increasing drought stress. This would be a first step towards accounting for lags between climate change, tree performance and distribution shifts.

\section{Conclusions}

Our findings demonstrate that the growth of major European tree species is constrained by drought in the rear edge, but genetic adaptations, ecological interactions and discrepancies between micro- and macroclimate conditions can alter the expected increase in aridity as we move southwards. We studied representative Pinaceae and Fagaceae species and found that they presented greater growth sensitivity to drought in southern than intermediate or northern sites within the rear edge. This was the case of 
Scots pine, European beech and silver fir. Given the great sensitivity to drought of some of the tree species studied in the rear-edge of their distribution and the expected increase in aridity as climate keeps warming, monitoring and conserving such populations is a fundamental tool to understand their resilience capacity. Dendrochronology provides tools to identify vulnerable populations based on their long-term responsiveness to drought. However, deciphering whether increased drought responsiveness results in enhanced forest vulnerability, including increased dieback and tree mortality rate, requires a more holistic approach. We combined dendrochronology with biogeography, but we lacked reliable information on the historical and ecological characteristics of each site allowing us to draw strong conclusions on why some intermediate or northern sites are equally or even more vulnerable to drought than their southern counterparts. Further studies will be improved by a better characterization of each site in terms of local features and potential genetic adaptations.

\section{Supplementary Information}

The online version contains supplementary material available at https://doi. org/10.1186/s40663-021-00303-1.

Additional file 1: Figure S1. Latitude of the studied sites showing different symbols which correspond to poleward or northern (blue triangles), intermediate (black circles) and equatorward or southern (red squares) sites. Figure S2. Temperature and precipitation trends of the six species (a, Pinus uncinata; b, Abies alba; c, Fagus sylvatica; $d$, Pinus sylvestris; e, Quercus robur; f, Quercus petraea) studied in the northern (blue lines and symbols), intermediate (black lines and symbols) and southern (brown lines and symbols) tree populations for the period 1950-2006. Figure S3. Mean tree-ring width series of the six species (a, Pinus uncinata; b, Abies alba; c, Fagus sylvatica; $d$, Pinus sylvestris; e, Quercus robur; f, Quercus petraea) studied in the northern (blue lines), intermediate (black lines) and southern or rear-edge (brown lines) populations considering the period 1900-2018. Figure S4. Significance of the moving window correlations calculated between mean site series of ringwidth indices of north, intermediate and south tree populations and monthly temperature data from previous September to September in the year of tree-ring formation. Previous and current months are abbreviated by lower- and upper-case letters, respectively. Moving correlations were obtained for 30-year intervals shifted by one year and the middle year of the interval is shown in $x$ axes for each species ( $a$, Pinus uncinata; $b$, Abies alba; c, Fagus sylvatica; d, Pinus sylvestris; e, Quercus robur; f, Quercus petraea). The colour scale shows the significance $(p<0.05)$ of the Pearson correlation coefficients (blue, significant negative values; red, significant positive values). Figure S5. Significance of the moving window correlations calculated between mean site series of ring-width indices of north, intermediate and south tree populations and monthly precipitation data from previous September to September in the year of tree-ring formation. Moving correlations were obtained for 30-year intervals shifted by one year and the middle year of the interval is shown in $x$ axes for each species (a, Pinus uncinata; b, Abies alba; c, Fagus sylvatica; d, Pinus sylvestris; e, Quercus robur; f, Quercus petraea). The colour scale shows the significance $(p<0.05)$ of the Pearson correlation coefficients (blue, significant negative values; red, significant positive values). Figure S6. Significance of the moving window correlations calculated between mean site series of ring-width indices of north, intermediate and south tree populations and the June SPEI drought index at 1-, 3-, 6-, 9-, 12-, 15-, 18-, and 21-month temporal resolutions ( $y$ axes). Moving correlations were obtained for 30-year intervals shifted by one year and the middle year of the interval is shown in $x$ axes for each species (a, Pinus uncinata; b, Abies alba; c, Fagus sylvatica; d, Pinus sylvestris; e, Quercus robur; f, Quercus petraea). The colour scale shows the significance $(p<0.05)$ of the Pearson correlation coefficients (red, significant positive values).

\section{Acknowledgements}

We thank the logistical support of Government Aragón Forest Service and the help for tree sampling of Rubén Camarero Jiménez and David Cuesta Redondo at Poyales and Valdemeca sites, respectively.

\section{Authors' contributions}

JJC designed the study and developed the main hypotheses, GSB, JJC, SMVS collected and prepared the data, AG analyzed the data and drafted the manuscript. All authors commented preliminary versions of the manuscript and contributed to improve the final version. The author(s) read and approved the final manuscript.

\section{Funding}

We acknowledge funding by project RTI2018-096884-B-C31 (Spanish Ministry of Science). G. S-B. is supported by a Spanish Ministry of Economy, Industry, and Competitiveness Postdoctoral grant (FJCl 2016-30121; FEDER funds).

\section{Availability of data and materials}

The datasets used and/or analysed during the current study are available from the corresponding author on reasonable request.

\section{Declarations}

Ethics approval and consent to participate Not applicable.

\section{Consent for publication}

Not applicable.

\section{Competing interests}

The authors declare that they have no competing interests.

\section{Author details}

${ }^{1}$ Instituto Pirenaico de Ecología (IPE-CSIC), Avda. Montañana 1005, E-50192 Zaragoza, Spain. ${ }^{2}$ EiFAB- iuFOR, University of Valladolid, Campus Duques de Soria, E-42004 Soria, Spain. ${ }^{3} \mathrm{NIBIO}$, Norwegian Institute of Bioeconomy Research, Postboks 155, NO-1431 Ås, Norway. ${ }^{4}$ Department of Biology, Wilfrid Laurier University, N2L 3C5, 75 Univ. Avenue W, Waterloo, Ontario, Canada.

Received: 3 December 2020 Accepted: 26 March 2021

Published online: 08 April 2021

\section{References}

Alla AQ, Camarero JJ (2012) Contrasting responses of radial growth and wood anatomy to climate in a Mediterranean ring-porous oak: implications for its future persistence or why the variance matters more than the mean. Eur J For Res 131(5):1537-1550. https://doi.org/10.1007/s10342-012-0621-x

Allen CD, Macalady H, Chenchouni D, Bachelet N, Mcdowell M, Vennetier T, Kitzberger T, Rigling A, Breshears DD, Hogg EH, Gonzalez P, Fensham R, Zhang Z, Castro J, Demidova N, Lim J-H, Allard G, Running SW, Semercis S, Cobb N (2010) A global overview of drought and heat induced tree mortality reveals emerging climate change risks for forests. For Ecol Manag 259(4):660-684. https://doi.org/10.1016/j.foreco.2009.09.001

Anderegg LDL, HilleRisLambers J (2016) Drought stress limits the geographic ranges of two tree species via different physiological mechanisms. Glob Ch Biol 22(3):1029-1045. https://doi.org/10.1111/gcb.13148

Anderegg LDL, HilleRisLambers J (2019) Local range boundaries vs. large-scale trade-offs: climatic and competitive constraints on tree growth. Ecol Lett 22(5):787-796. https://doi.org/10.1111/ele.13236

Anderegg WRL, Anderegg LDL, Kerr KL, Trugman AT (2019) Widespread droughtinduced tree mortality at dry range edges indicates that climate stress exceeds species' compensating mechanisms. Glob Ch Biol 25(11):3793-3802. https://doi.org/10.1111/gcb.14771

Anderegg WRL, Kane JM, Anderegg LDL (2013) Consequences of widespread tree mortality triggered by drought and temperature stress. Nat Clim Ch 3(1): 30-36. https://doi.org/10.1038/nclimate1635 
Anderegg WRL, Schwalm C, Biondi F, Camarero JJ, Koch G, Litvak M, Ogle K, Shaw JD, Shevliakova E, Williams AP, Wolf A, Ziaco E, Pacala S (2015) Pervasive drought legacies in forest ecosystems and their implications for carbon cycle models. Science 349(6247):528-532. https://doi.org/10.1126/ science.aab1833

Aranda I, Gil L, Pardos JA (2000) Water relations and gas exchange in Fagus sylvatica L. and Quercus petraea (Mattuschka) Liebl. In a mixed stand at their southern limit of distribution in Europe. Trees Struct Funct 14(6):344-352. https://doi.org/10.1007/s004680050229

Babst F, Bouriaud O, Poulter B, Trouet V, Girardin MP, Frank DC (2019) Twentieth century redistribution in climatic drivers of global tree growth. Sci Adv 5: eaat4313

Barbeta A, Camarero JJ, Sangüesa-Barreda G, Muffler L, Peñuelas J (2019) Contrasting effects of fog frequency on the radial growth of two tree species in a Mediterranean-temperate ecotone. Agric For Meteorol 264:297-308. https://doi.org/10.1016/j.agrformet.2018.10.020

Bose AK, Gessler A, Bolte A, Bottero A, Buras A, Cailleret M, Camarero JJ, Haeni M, Hereş A-M, Hevia A, Lévesque M, Linares JC, Martinez-Vilalta J, Matías L, Menzel A, Sánchez-Salquero R, Saurer M, Vennetier M, Ziche D, Rigling A (2020) Growth and resilience responses of scots pine to extreme droughts across Europe depend on pre-drought growth conditions. Glob Ch Biol 26(8): 4521-4537. https://doi.org/10.1111/gcb.15153

Breheny P, Burchett W (2017) Visualization of regression models using visreg. The R J 9(2):56-71. https://doi.org/10.32614/RJ-2017-046

Bunn AG (2008) A dendrochronology program library in $R(d p / R)$. Dendrochronologia 26(2):115-124. https://doi.org/10.1016/j.dendro.2008. 01.002

Camarero JJ, Bigler C, Linares JC, Gil-Pelegrín E (2011) Synergistic effects of past historical logging and drought on the decline of Pyrenean silver fir forests. For Ecol Manag 262(5):759-769. https://doi.org/10.1016/j.foreco.2011.05.009

Camarero JJ, Gazol A, Sangüesa-Barreda G, Oliva J, Vicente-Serrano SM (2015) To die or not to die: early-warning signals of dieback in response to a severe drought. J Ecol 103(1):44-57. https://doi.org/10.1111/1365-2745.12295

Camarero JJ, Guerrero-Campo J, Gutiérrez E (1998) Tree-ring growth and structure of Pinus uncinata and Pinus sylvestris in the central Spanish Pyrenees. Arct Antarct Alp Res 30(1):1-10. https://doi.org/10.2307/1551739

Camarero JJ, Linares JC, Sangüesa-Barreda G, Sánchez-Salguero R, Gazol A, Navarro-Cerrillo RM, Carreira JA (2017) The multiple causes of forest decline in Spain: drought, historical logging, competition and biotic stressors. In: Amoroso M, Daniels L, Baker P, Camarero JJ (eds) Dendroecology. Springer, New York, pp 307-323. https://doi.org/10.1007/978-3-319-61669-8_13

Caudullo G, Welk E, San-Miguel-Ayanz J (2017) Chorological maps for the main European woody species. Data Brief 12:662-666. https://doi.org/10.1016/j. dib.2017.05.007

Cavin L, Jump AS (2017) Highest drought sensitivity and lowest resistance to growth suppression are found in the range core of the tree Fagus sylvatica $\mathrm{L}$. not the equatorial range edge. Glob Ch Biol 23(1):362-379. https://doi.org/1 $0.1111 /$ gcb. 13366

Choat B, Brodribb TJ, Brodersen CR, Duursma RA, López R, Medlyn BE (2018) Triggers of tree mortality under drought. Nature 558(7711):531-539. https:// doi.org/10.1038/s41586-018-0240-x

Cook ER, Peters K (1981) The smoothing spline: a new approach to standardizing forest interior tree-ring width series for dendroclimatic studies. Tree-Ring Bull 41:45-53

Corcuera L, Camarero JJ, Sisó S, Gil-Pelegrín E (2006) Radial-growth and woodanatomical changes in overaged Quercus pyrenaica coppice stands: functional responses in a new Mediterranean landscape. Trees Struct Funct 20(1):91-98. https://doi.org/10.1007/s00468-005-0016-4

Core Team R (2020) R: a language and environment for statistical computing. $R$ Foundation for Statistical Computing, Vienna

de Vries SMG, Alan M, Bozzano M, Burianek V, Collin E, Cottrell J, Ivankovic M, Kelleher C, Koskela J, Rotach P, Vietto L, Yrjänä L (2015) Pan-European strategy for genetic conservation of forest trees and establishment of a core network of dynamic conservation units. European Forest Genetic Resources Programme (EUFORGEN), Bioversity International, Rome

Dobbertin M (2005) Tree growth as indicator of tree vitality and of tree reaction to environmental stress: a review. Eur J For Res 124(4):319-333. https://doi. org/10.1007/s10342-005-0085-3

Dorado-Liñán I, Piovesan G, Martínez-Sancho E, Gea-lzquierdo G, Zang C, Cañellas I, Castagneri D, Di Filippo A, Gutiérrez E, Ewald J, Fernández-de-Uña L, Hornstein D, Jantsch MC, Levanič T, Mellert KH, Vacchiano G, Zlatanov T, Menzel A (2019)
Geographical adaptation prevails over species-specific determinism in trees' vulnerability to climate change at Mediterranean rear-edge forests. Glob Ch Biol 25(4):1296-1314. https:/doi.org/10.1111/gcb.14544

Dunnett CW (1980) Pairwise multiple comparisons in the unequal variance case. Am Stat Assoc 75(372):796-800. https://doi.org/10.1080/01621459.1980.104 77552

Fick SE, Hijmans RJ (2017) WorldClim 2: new 1-km spatial resolution climate surfaces for global land areas. Int J Climatol 37(12):4302-4315. https://doi. org/10.1002/joc.5086

Fritts HC (1976) Tree rings and climate. Academic Press, London

Galván D, Camarero JJ, Gutiérrez E (2014) Seeing the trees for the forest: drivers of individual growth responses to climate in Pinus uncinata mountain forests. J Ecol 102(5):1244-1257. https://doi.org/10.1111/1365-2745.12268

Gazol A, Camarero JJ, Gutiérrez E, Popa I, Andreu-Hayles L, Motta R, Nola P, Ribas M, Sangüesa-Barreda G, Urbinati C, Carrer M (2015) Distinct effects of climate warming on populations of silver fir (Abies alba) across Europe. J Bioegogr 42(6):1150-1162. https://doi.org/10.1111/jbi.12512

Gazol A, Camarero JJ, Sangüesa-Barreda G, Vicente-Serrano SM (2018) Postdrought resilience after forest die-off: shifts in regeneration, composition, growth and productivity. Front Plant Sci 9:1546. https://doi.org/10.3389/fpls.2 018.01546

Gazol A, Sangüesa-Barreda G, Camarero JJ (2020) Forecasting forest vulnerability to drought in Pyrenean silver fir forests showing dieback. Front For Glob Ch 3:1-13

González-Díaz P, Gazol A, Valbuena-Carabaña M, Sangüesa-Barreda G, Moreno Urbano A, Zavala MA, Camarero JJ (2020) Remaking a stand: links between genetic diversity and tree growth in expanding mountain pine populations. For Ecol Manag 472:118244. https://doi.org/10.1016/j.foreco.2020.118244

Granda E, Alla AQ, Laskurain NA, Loidi J, Sánchez-Lorenzo A, Camarero JJ (2017) Coexisting oak species, including rear-edge populations, buffer climate stress through xylem adjustments. Tree Physiol 38:159-172

Hampe A (2004) Bioclimate envelope models: what they detect and what they hide. Glob Ecol Biogeogr 13(5):469-471. https://doi.org/10.1111/j.1466-822X.2 004.00090.x

Hartmann H, Moura CF, Anderegg WRL, Ruehr NK, Salmon Y, Allen CD, Arndt SK, Breshears DD, Davi H, Galbraith D, Ruthrof KX, Wunder J, Adams HD, Bloemen J, Cailleret M, Cobb R, Gessler A, Grams TEE, Jansen S, Kautz S, Lloret F, O'Brien M (2018) Research frontiers for improving our understanding of drought-induced tree and forest mortality. New Phytol 218(1):15-28. https://doi.org/10.1111/nph.15048

Haylock MR, Hofstra N, Klein Tank AMG, Klok EJ, Jones PD, New M (2008) A European daily high-resolution gridded dataset of surface temperature and precipitation. J Geophys Res-Atmos 113(D20):D20119. https://doi.org/10.102 9/2008JD010201

Herrero A, Rigling A, Zamora R (2013) Varying climate sensitivity at the dry distribution edge of Pinus sylvestris and P. nigra. For Ecol Manag 308:50-61. https://doi.org/10.1016/j.foreco.2013.07.034

Holmes R (1983) Computer-assisted quality control in tree-ring dating and measurement. Tree-Ring Bull 43:69-78

Jump AS, Ruiz-Benito P, Greenwood S, Allen CD, Kitzberger T, Fensham R, Martínez-Vilalta J, Lloret F (2017) Structural overshoot of tree growth with climate variability and the global spectrum of drought-induced forest dieback. Glob Ch Biol 23(9):3742-3757. https://doi.org/10.1111/gcb.13636

Klein T (2014) The variability of stomatal sensitivity to leaf water potential across tree species indicates a continuum between isohydric and anisohydric behaviours. Funct Ecol 28(6):1313-1320. https://doi.org/10.1111/1365-243 5.12289

Leuschner C (2020) Drought response of European beech (Fagus sylvatica L.) - a review. Persp Plant Ecol Evol Syst 47:125576

Lindner M, Maroschek M, Netherer S, Kremer A, Barbati A, Garcia-Gonzalo J, Marchetti M (2010) Climate change impacts, adaptive capacity, and vulnerability of European forest ecosystems. For Ecol Manag 259(4):698-709. https://doi.org/10.1016/j.foreco.2009.09.023

Marqués L, Camarero JJ, Gazol A, Zavala MA (2016) Drought impacts on tree growth of two pine species along an altitudinal gradient and their use as early-warning signals of potential shifts in tree species distributions. For Ecol Manag 381:157-167. https://doi.org/10.1016/j.foreco.2016.09.021

Marqués L, Madrigal-González J, Zavala MA, Camarero JJ, Hartig F (2018) Lastcentury forest productivity in a managed dry-edge scots pine population: the two sides of climate warming. Ecol Appl 28(1):95-105. https://doi.org/1 0.1002/eap.1631 
Martínez-Vilalta J, Cochard H, Mencuccini M, Sterck F, Herrero A, Korhonen JFJ, Zweifel R (2009) Hydraulic adjustment of scots pine across Europe. New Phytol 184(2):353-364. https://doi.org/10.1111/j.1469-8137.2009.02954.x

Meko DM, Touchan R, Anchukaitis KJ (2011) Seascorr: a MATLAB program for identifying the seasonal climate signal in an annual tree-ring time series. Comput Geosci 37(9):1234-1241. https://doi.org/10.1016/j.cageo.2011.01.013

Molina-Valero JA, Camarero JJ, Álvarez-González JG, Cerioni M, Hevia A, SánchezSalguero R, Martín-Benito D, Pérez-Cruzado C (2021) Mature forests hold maximum live biomass stocks. For Ecol Manag 480:118635. https://doi.org/1 0.1016/j.foreco.2020.118635

Muffler L, Weigel R, Hacket-Pain AJ, Klisz M, van der Maaten E, Wilmking M, Kreyling J, van der Maaten-Theunissen M (2020) Lowest drought sensitivity and decreasing growth synchrony towards the dry distribution margin of European beech. J Biogeogr 47(9):1910-1921. https://doi.org/10.1111/jbi.13884

Pasho E, Camarero JJ, de Luis M, Vicente-Serrano SM (2011) Impacts of drought at different time scales on forest growth across a wide climatic gradient in North-Eastern Spain. Agric For Meteorol 151(12):1800-1811. https://doi.org/ 0.1016/j.agrformet.2011.07.018

Peaucelle M, Janssens IA, Stocker BD, Descals Ferrando A, Fu YH, MolownyHoras R, Ciais P, Peñuelas J (2019) Spatial variance of spring phenology in temperate deciduous forests is constrained by background climatic conditions. Nat Commun 10(1):5388. https://doi.org/10.1038/s41467-01 9-13365-1

Peltier DM, Ogle K (2020) Tree growth sensitivity to climate is temporally variable. Ecol Lett 23(11):1561-1572. https://doi.org/10.1111/ele.13575

Pérez-Luque AJ, Gea-Izquierdo G, Zamora R (2020) Land-use legacies and climate change as a double challenge to oak forest resilience: mismatches of geographical and ecological rear edges. Ecosystems. 1:1. https://doi.org/10.1 007/s10021-020-00547-y

Rozas V (2001) Detecting the impact of climate and disturbances on tree-rings of Fagus sylvatica L. and Quercus robur L. in a lowland forest in Cantabria, northern Spain. Ann For Sci 58(3):237-251. https://doi.org/10.1051/forest:2 001123

Rozas V, Camarero JJ, Sangüesa-Barreda G, Souto M, García-González I (2015) Summer drought and ENSO-related cloudiness distinctly drive Fagus sylvatica growth near the species rear-edge in northern Spain. Agric For Meteorol 201 153-164. https://doi.org/10.1016/j.agrformet.2014.11.012

Rubio-Cuadrado A, Camarero JJ, Gordaliza GG, Cerioni M, Montes F, Gil L (2020) Competition overrides climate as trigger of growth decline in a mixed Fagaceae Mediterranean rear-edge forest. Ann For Sci 77(4):94. https://doi. org/10.1007/s13595-020-01004-5

Sánchez-Salguero R, Camarero JJ, Gutiérrez E, González Rouco F, Gazol A, Sangüesa-Barreda G, Andreu-Hayles L, Linares JC, Seftigen K (2017) Assessing forest vulnerability to climate warming using a process-based model of tree growth: bad prospects for rear edges. Glob Ch Biol 23(7):2705-2719. https:// doi.org/10.1111/gcb.13541

Serra-Maluquer X, Gazol A, Sangüesa-Barreda G, Sánchez-Salguero R, Rozas V, Colangelo M, Gutiérrez E, Camarero JJ (2019) Geographically structured growth decline of rear-edge Iberian Fagus sylvatica forests after the 1980s shift toward a warmer climate. Ecosystems 22(6):1325-1337. https://doi.org/1 0.1007/s10021-019-00339-z

Serreze MC, Barry RG (2011) Processes and impacts of Arctic amplification: a research synthesis. Glob Planet Ch 77(1-2):85-96. https://doi.org/10.1016/j. gloplacha.2011.03.004

Svenning J-C, Sandel B (2013) Disequilibrium vegetation dynamics under future climate change. Am J Bot 100(7):1266-1286. https://doi.org/10.3732/ajb.12 00469

Talluto MW, Boulangeat I, Vissault S, Thuiller W, Gravel D (2007) Extinction debt and colonization credit delay range shifts of eastern north American trees. Nat Ecol Evol 1:182

Tardif J, Camarero JJ, Ribas M, Gutiérrez E (2003) Spatiotemporal variability in tree ring growth in the Central Pyrenees: climatic and site influences. Ecol Monogr 73(2):241-257. https://doi.org/10.1890/0012-9615(2003)073[0241:SVIT $\mathrm{Gl}] 2.0 \cdot \mathrm{CO} ; 2$

Valladares F, Matesanz S, Guilhaumon F, Araújo MB, Balaguer L, Benito-Garzón M, Cornwell W, Gianoli E, van Kleunen M, Naya DE, Nicotra AB, Poorter H, Zavala MA (2015) The effects of phenotypic plasticity and local adaptation on forecasts of species range shifts under climate change. Ecol Lett 17:1351-1364

Vicente-Serrano SM, Beguería S, López-Moreno Jl (2010) A multiscalar drought index sensitive to global warming: the standardized precipitation evapotranspiration index. J Clim 23(7):1696-1718. https://doi.org/10.1175/2 009JCLI2909.1

Vicente-Serrano SM, Camarero JJ, Zabalza J, Sangüesa-Barreda G, López-Moreno J, Tague CL (2015) Evapotranspiration deficit controls net primary production and growth of silver fir: implications for Circum-Mediterranean forests under forecasted warmer and drier conditions. Agric For Meteorol 206:45-54. https://doi.org/10.1016/j.agrformet.2015.02.017

Vicente-Serrano SM, Tomas-Burguera M, Beguería S, Reig F, Latorre B, PeñaGallardo M, Luna MY, Morata A, González-Hidalgo JC (2017) A high resolution dataset of drought indices for Spain. Data 2(3):22. https://doi.org/1 0.3390/data2030022

Vilà-Cabrera A, Jump AS (2019) Greater growth stability of trees in marginal habitats suggests a patchy pattern of population loss and retention in response to increased drought at the rear edge. Ecol Lett 22(9):1439-1448. https://doi.org/10.1111/ele.13329

Vilà-Cabrera A, Premoli AC, Jump AS (2019) Refining predictions of population decline at species' rear edges. Glob Ch Biol 25(5):1549-1560. https://doi.org/1 $0.1111 / \mathrm{gcb} .14597$

Vitasse Y, Bottero A, Cailleret M, Bigler C, Fonti P, Gessler A, Lévesque M, Rohner B, Weber P, Rigling A, Wohlgemuth T (2019) Contrasting resistance and resilience to extreme drought and late spring frost in five major European tree species. Glob Ch Biol 25(11):3781-3792. https://doi.org/10.1111/gcb.14803

Wilmking $M$, van der Maaten-Theunissen $M$, van der Maaten $E$, Scharnweber T, Buras A, Biermann C, Gurskaya M, Hallinger M, Lange J, Shetti R, Smiljanic M, Trouillier M (2020) Global assessment of relationships between climate and tree growth. Glob Ch Biol 26(6):3212-3220. https://doi.org/10.1111/gcb.15057

Zang C, Biondi F (2015) Treeclim: an R package for the numerical calibration of proxy-climate relationships. Ecography 38(4):431-436. https://doi.org/10.1111/ ecog.01335

\section{Submit your manuscript to a SpringerOpen ${ }^{\circ}$ journal and benefit from:}

- Convenient online submission

- Rigorous peer review

- Open access: articles freely available online

High visibility within the field

- Retaining the copyright to your article

Submit your next manuscript at $\boldsymbol{\nabla}$ springeropen.com 